\title{
Feeding and social behavior of the piabanha, Brycon devillei (Castelnau, 1855) (Characidae: Bryconinae) in the wild, with a note on following behavior
}

\author{
Pedro G. Azevedo, Rafael M. C. Melo and Robert J. Young
}

Knowledge concerning the behavior of wild freshwater fishes in Brazil is restricted to a few studies, despite such studies being able to answer fundamental questions about conservation. Species of Brycon are amongst the most threatened in the Neotropics, particularly in southeast Brazil, due to anthropogenic activities in this region. This study investigated the feeding and social behaviors of the endangered fish, Brycon devillei in the Preto River, Jequitinhonha basin, Minas Gerais State, Brazil. Behavioral data were collected by snorkeling with four spatially separated groups (habituated), and direct observations of shoals were made using an underwater video camera (a total of 448 hours of observations). This species showed diverse tactics to obtain food. However, the species proved to be predominately a specialist surface-picker, which adopted alternative tactics to find food at certain times of the year, most notably when food items on the water surface became low. Feeding frequency was shown to be negatively correlated to agonistic behavior between conspecifics. Feeding associations were also recorded between the anostomid Leporinus garmani, acting as a nuclear species, and $B$. devillei, as follower species. The data presented here showed the importance of conserving the riparian environment to protect $B$. devillei populations. Furthermore, the present study included rare observations of nuclear-follower feeding association among freshwater fishes, especially between medium-sized characiforms, being the first observations of such kind in a Cerrado stream.

O conhecimento do comportamento de vida livre em peixes de água doce brasileiros é restrito a poucos estudos e pode responder a questões fundamentais de conservação. Espécies do gênero Brycon estão entre as mais ameaçadas na região neotropical, especialmente no sudeste brasileiro, em vista de diversos impactos antrópicos. O presente estudo investigou os comportamentos alimentar e social de Brycon devillei no rio Preto, bacia do Jequitinhonha, Brasil. Para tanto, utilizou-se seções de mergulhos livres para observação direta de quatro grupos habituados de $B$. devillei, com o auxílio de câmeras filmadoras subaquáticas. Tal espécie apresentou variadas táticas para obtenção de alimento. Entretanto, a espécie demonstrou ser um forrageador de superfície especializado que, em determinados períodos do ano, quando provavelmente a lâmina d'água torna-se uma fonte escassa de recursos, adota táticas alternativas em busca de alimentos. A frequência de forrageamento demonstrou ser negativamente correlacionada com os comportamentos agonísticos. Foram observadas associações alimentares interespecíficas envolvendo o timburé, Leporinus garmani, como espécie nuclear, e a piabanha, Brycon devillei, como sua seguidora. Os dados apresentados no presente estudo demonstram a importância de se conservar o ambiente ripário em prol da proteção das populações de $B$. devillei. Além disso, o presente estudo é um dos raros registros de associação alimentar do tipo nuclear-seguidor entre peixes de água doce, especialmente entre espécies de médio porte, e o primeiro deste tipo para riachos de Cerrado.

Key words: Feeding association, Feeding tactics, Jequitinhonha basin, Natural history, Underwater observations.

\section{Introduction}

Underwater studies on Neotropical fish have revealed a wide diversity of behavioral adaptations for obtaining food, including many specialized and complex interactions between species, such as: nibbler, cleaner and nuclear-follower (Sazima,
1986; Casatti, 2002; Carvalho et al., 2003; Zuanon et al., 2006; Teresa \& Carvalho, 2008). Moreover, these studies have answered central issues concerning the dynamics of schools (Fréon et al., 1992), as well as social interactions with other groups of vertebrates (e.g. turtles, dolphins and primates) and invertebrates (Sabino \& Sazima, 1999; Sazima et al., 2004;

Programa de Pós Graduação em Zoologia de Vertebrados, Pontifícia Universidade Católica de Minas Gerais, $30535-610$ Belo Horizonte, MG, Brazil. pedraoga@yahoo.com.br (PGA); robyoung@pucminas.br (RJY) 
Sazima \& Grossman, 2006; Sazima et al., 2006). However, Azevedo et al. (2010) reported that, despite the efforts of Brazilian researchers to increase knowledge regarding the behavior of Neotropical freshwater fish, the number of published studies is still limited, and insufficient to answer basic questions (i.e. the critical role that the interruption of reproductive activities has played in fishes and how knowledge of reproductive behavior can aid in recovery efforts; the interrelation between habitat loss, habitat choice, and habitat protection; understanding the intricacy and diversity of behavioral interactions between predators and prey and their impact on biodiversity loss). Therefore, this subject clearly deserves more attention.

There is, for example, a wealth of literature on the adaptive significance of multi-species feeding associations for bird species (Crook, 1965; Cody, 1971; Krebs, 1973; Bertram, 1978). However, studies concerning the ecological significance of foraging associations are recent and restricted to few studies for fish (Lukoschek \& McCormick, 2000), and even more rare for those species from Neotropical freshwaters (Sazima, 1986; Teresa \& Carvalho, 2008; Leitão et al., 2007; Garrone-Neto \& Sazima, 2009). Following association between fishes involves an opportunistic species following one or more foraging nuclear species (mainly bottom-diggers). The followers benefit from food uncovered or flushed out when the nuclear fish disturbs the riverbed (Fricke, 1975; Strand, 1988).

In order to help fill out these gaps in the knowledge concerning Neotropical freshwater fishes, we studied herein the feeding and social behaviors of Brycon devillei (Castelnau, 1855) on Preto River, Jequitinhonha basin. The genus Brycon Müller \& Troschel is widespread over the Neotropical region, and comprises 44 nominal species described for cisandean rivers of South America (Lima, 2003, 2004). Species in this genus are among the most endangered in Brazilian rivers and have been since the 1970s (Godoy, 1975); they have become particularly rare in the developed southeast region of Brazil due to anthropogenic activities (e.g. Lima \& Castro, 2000; Agostinho et al., 2008; Lima et al., 2008; Albrecht et al., 2009). Currently, six species of the genus are included in the regional list of species threatened with extinction (Rosa \& Lima, 2005), one of which is Brycon devillei, the target species of the present study. Considering the extensive geographical range and vulnerability of species in this genus, studies of Brycon in natural environments remain remarkably rare (e.g. Lowe-McConnell, 1964; Menezes, 1969; Burcham, 1988; Horn, 1997; Banack et al., 2002). Little is known about the ecology of the species Brycon devillei, which was reported by Godinho et al. (1999; as B. insignis) as being mainly insectivorous. The largest standard lengths for the species are $254.0 \mathrm{~mm}$ for males and $342.0 \mathrm{~mm}$ for females (Godinho et al., 1999).

The goal of this study was to investigate the feeding tactics and social behavior of the endangered Brycon devillei in the wild. It was predicted that this species would display a wide range of foraging behaviors due to the omnivorous nature of the species of the genus (Lima, 2003). It was also predicted that the species would demonstrate interspecific social interactions, as described in other studies concerning other characids (Sazima, 1986; Teresa \& Carvalho, 2008).

\section{Material and Methods}

\section{Study site}

The rio Preto State Park (RPSP) (4330'676”W 1800'799”S) is located in the state of Minas Gerais, on the southern-central portion of the Espinhaço Mountain Range, in southeast Brazil. It was created to protect the headwaters of the Preto River, which is considered an important contributor to the Jequitinhonha River Basin. The park's 12,000 ha of Cerrado vegetation have been transformed into a Permanent Protection Area since 1994. Forty-one fish species are known in the Jequitinhonha River Basin (Godinho et al., 1999), of which twenty occur in the park or in its surroundings (Gilmar B. Santos, pers. comm.).

The climate in this region can be classified as tropical wet (sensu Ab'Saber, 1977), with the presence of two well defined seasons: a wet, warm season from October to March and a dry, cold season from April to September. Annual rainfall values for the region (from 1995 to 2003) show a mean of $1,351.22 \mathrm{~mm}$. Annual temperature values show a mean of $18.96^{\circ} \mathrm{C}$ and relative air moisture content of $81 \%$ (Oliveira \& Eterovick, 2010).

The present study was conducted in rio Preto, a permanent lotic ecosystem within the park, which includes high areas (850 to $1,826 \mathrm{~m}$ ) of the Espinhaço Mountain Range. The riverside is composed mainly of two types of landscape: on the highest ground on sandstone, there is an open vegetation formation (herbaceous and bushy strata, as well as rocky outcrops along its margins); in the lower regions, the riparian zone is composed of Semi deciduous Forest, due to the greater availability of moisture and organic matter (Rizzini, 1979). Substrate composition in the riverbed and margins varies from rocky to sandy, this last one being slightly more abundant in lower regions. There is also the occurrence of fine particulate substrates, composed mainly of silt. The presence of living green vegetation on the riverbed can be considered scarce, and the occurrence of leaf-litter layers of allochthonous origin was most evident where riparian vegetation was most developed.

\section{Field work}

In February 2006 a pilot project was undertaken to evaluate the possibility of using free diving as an observation method, and to choose the sampling points. Four sampling sites were chosen taking into account the local abundance of individuals of Brycon devillei. To avoid replicated observations of fish, the sampling sites chosen had a minimum distance of $1.5 \mathrm{~km}$ from each other.

Field observations were divided into two periods. The first one was conducted between April 2006 and January 2007, when four quarterly campaigns of four days each were undertaken. The second period was carried out between August 2008 and July 2009, with the undertaking of twelve 
monthly campaigns of eight days each. Two diving sessions were performed daily, interspersed between morning and evening, each lasting 120 minutes. A total of 224 dives and 448 hours of observation were made. For the sequence of observations at the sampling points a Latin Square (Zar, 1999) experimental design was applied to avoid sampling one particular group, always, at the same time of day.

For the collection of behavioral data of $B$. devillei, direct observations of fish were made during snorkeling. The observation method adopted was "scan with instantaneous recording of observations every 120 seconds" (Lehner, 1998). If the number of fish to be observed was more than 10 individuals, then only the 10 individuals closest to the observer had their behavior recorded ( $c f$. Lehner, 1998). Before beginning observations a visual count of the number of fish of the study species in each sampling site was made.

At all sampling sites, a series of preliminary observations were undertaken to allow fish to become acclimatized to the observer's presence and to make initial observations of fish. Data to be recorded were first assessed in a series of preliminary dives and then, during actual observation sessions, behavioral events were recorded on an acrylic pad or with underwater video cameras. Special attention was paid to the modes employed by fish to obtain food and to social behaviors. Observations were conducted in a calm and quiet manner, causing minimal disturbance in the water, as recommended by Sazima \& Machado (1990). In addition to such precautions, we respected a minimum distance (approximately $2.0 \mathrm{~m}$ ) from the fish so that the presence of observer did not represent a threat, as described by Lehner (1998).

Additionally, we performed diurnal direct observations of the association between individuals of Leporinus garmani Borodin, 1929 and $B$. devillei while snorkeling, using the sequence sampling method - a kind of continuous recording sampling, used when the focus is on a chain of behaviors ( $c f$. Lehner, 1998). Field surveys were conducted monthly between August 2008 and July 2009. Diving sessions were performed four times per campaign, interspersed between morning and evening, each lasting $120 \mathrm{~min}$. A total of 48 dives and 96 hours of observation were carried out. To standardize data collection and minimize errors, all observations were made by the same observer (PGA).

Twelve specimens of $B$. devillei were captured in locations different from the sampled groups and sent to the Zoology Museum at the University of São Paulo for taxonomic confirmation and cataloging. Voucher specimens of B. devillei were deposited in the Fish Collection of the Zoology Museum at the University of São Paulo (MZUSP 101506, 101507, and 101508).

\section{Statistical analysis}

For data analysis, univariate statistical tests were conducted using Minitab $15^{\circ}$ and Statistica $7^{\circ}$ for Windows. To verify if the data met the requirements for parametric statistics an Anderson-Darling test was applied and data were found to meet the requirements for parametric statistics. For all statistical tests performed, the level of significance to reject the null hypothesis $\left(\mathrm{H}_{0}\right)$ was $5 \%(\alpha=0.05)$. For statistical analyses data were converted into mean values per group with each observation site representing a datum unit.

Foraging tactics were analyzed in several ways in accordance with the objectives of the study. To verify whether the tactics had statistically significant differences between them, a chi-square $\left(\chi^{2}\right)$ was used to compare the observed frequencies; and analysis of variance (One-Way ANOVA) was employed to compare the mean occurrence of tactics, followed by post-hoc comparisons using a Tukey test. To determine whether the variable "foraging tactics" was significantly different between seasons, a factorial analysis of variance (Two-Way ANOVA) was used (Zar, 1999).

To investigate the relationships between conspecific agonistic behavior and foraging frequency by $B$. devillei a Pearson's linear correlation was employed (Zar, 1999). Moreover, a Mann-Whitney test was performed to compare the observed frequencies between seasons for feeding association and agonistic behavior (Siegel, 1975).

\section{Results}

\section{Feeding and social behavior of Brycon devillei}

Three foraging tactics of $B$. deville $i$ were identified: (1) "surface-picking" was performed by using a quick or 'calm' capture of food items floating on the water's surface; (2) "digging" was an opportunistic behavior in which fish searched the riverbed substrate to bite at food items of various sizes, either animals or plants; (3) "active-hunting" was marked by elaborate hunting behavior (individuals or groups) of schools of small characins (Astyanax spp.). The hunting of small characins proved to be a highly coordinated event in which individuals of $B$. devillei segregated schools of their prey into small groups, and then cornered the prey fish on the riverside before consuming them. In only $1.05 \%$ of observations the food items ingested by $B$. devillei were identified due to the speed with which feeding events occurred and the distance of observation. In the case of active-hunting all prey were small characins.

The figure 1 illustrates the frequency with which each foraging tactic was adopted by $B$. devillei during the months of the study. Chi-square test $\left(\chi^{2}\right)$ showed a significant difference between the three tactics observed $\left(\chi^{2}=233.208, \mathrm{DF}=2, \mathrm{p}<0.001\right)$, and partitioned chi-square tests showed that all three pair wise comparisons were significantly different $(p<0.001$ in all cases), with surfacing-picking most expressed, then digging, and the least expressed was active hunting (Fig. 1). The variance analysis also showed a significant difference (One-Way ANOVA, F = $25.90, \mathrm{DF}=2.23, \mathrm{p}<0.001$ ), with "surface-picking" being the most employed tactic. Post-hoc Tukey's Test showed statistically significant interaction means only between "surface-picking versus active-hunting" and "digging versus active-hunting" ( $\mathrm{p}$ $<0.05$ in both cases). Subsequently, a factorial analysis of variance (Two-Way ANOVA) indicated a significant difference in feeding patterns between seasons $(\mathrm{F}=14.61, \mathrm{DF}=1.23, \mathrm{p}$ $<0.001)$ and between tactics by seasons $(F=78.11, D F=2.23, p$ 


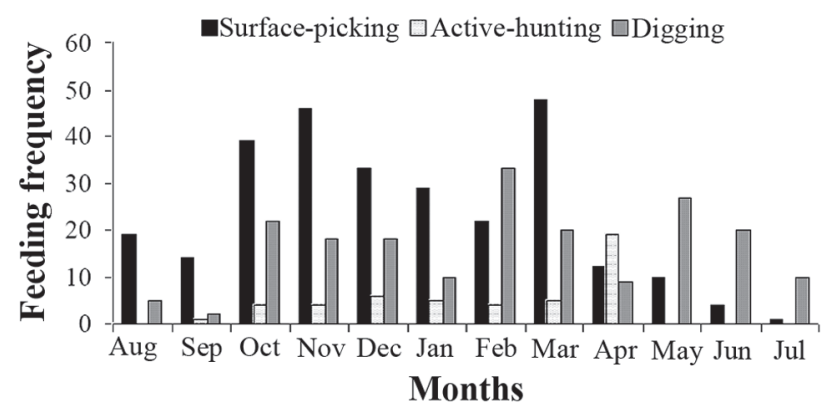

Fig. 1. Observed frequency of foraging tactics of Brycon devillei in the RPSP between April 2006 and July 2009.

$<0.001)$. During the rainy season "surface-picking" was significantly higher than in the dry season (Fig. 2).

The four sampling sites had the following mean number of fish of our study species ( \pm SD): $20.39 \pm 6.31,14.30 \pm 3.50$, $33.05 \pm 13.55$ and $35.93 \pm 5.91$. From the social point of view, $B$. devillei lived in shoals and showed agonistic behavior between conspecific individuals. This behavior was characterized by an instantaneous threat of aggression; however, no visible injuries resulted from this behavior. Agonistic behavior was more pronounced $(\mathrm{W}=57.0, \mathrm{~N}=6$, $\mathrm{P}<0.001)$ in the dry season $(74.7 \%)$ than in wet season $(25.2 \%)$. A Pearson's correlation between frequency of threats and frequency of feeding was significant and negative $(r=-0.867$, $\mathrm{N}=12, \mathrm{p}<0.001)$.

\section{Feeding association of nuclear-following behavior}

Nuclear-follower behavior between Leporinus garmani and Brycon devillei was recorded in all of the observation sessions $(\mathrm{N}=48)$. Such association was registered only when both fish species were situated near the stream channel bottom (water deeper than $1.5 \mathrm{~m}$ ) covered by leaf-litter layers of allochthonous origin on sand, in areas of low water flow (current speed of up to $5 \mathrm{~cm} / \mathrm{s}$ at the stream bottom); this behavior was manifested more frequently $(\mathrm{W}=53.0, \mathrm{~N}=6, \mathrm{p}<0.05)$ in the dry season $(76.9 \%)$ than in wet season $(23 \%)$. Feeding association was characterized by the presence of one to five individuals of $B$. devillei stationary in close proximity $(\mathrm{ca} .10 \mathrm{~cm})$ to one to three individuals of $L$. garmani (Fig. 3). In this configuration, $B$. devillei adopted a sit-and-wait foraging tactic (sensu Sazima, 1986) to feed on any abundant food item (e.g. plant debris and benthic invertebrates) disturbed by the anostomids. Individuals of L. garmani were observed foraging singly or in groups (up to three individuals) on sand banks, excavating the soft substrate with their sub-terminal mouth and filling it with sediment. The non usable mass from the mouthful was expelled through the opercular openings and/or mouth, producing a fine cloud of sediment [see Sazima (1986) for examples of a similar digging tactic in Satanoperca pappaterra]. During foraging the anostomids also disturbed the stream bottom with movements of their pectoral fins. Throughout observation sessions this feeding tactic lasted a mean of $27.4 \mathrm{~min} \pm 12.3(\mathrm{~N}=$ 67 ) and occurred during $81.8 \%$ of observation time. Frequently,

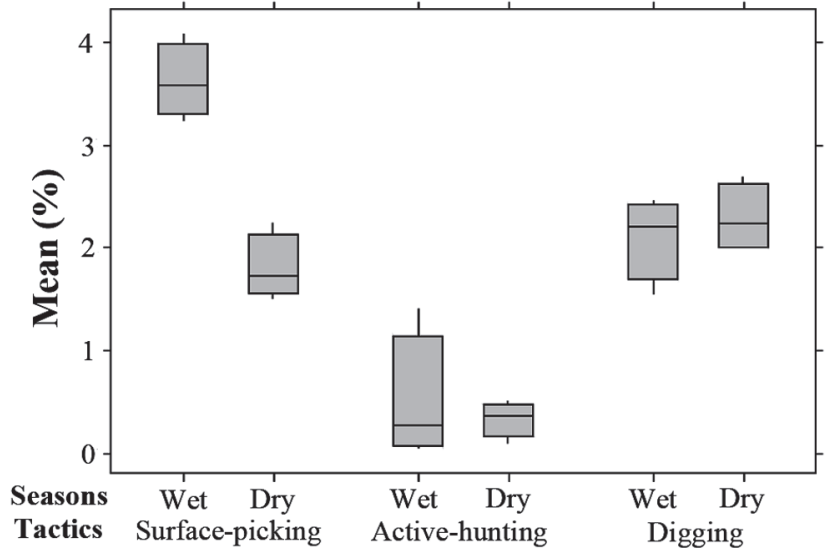

Fig. 2. Mean values of proportion of time expressing different foraging tactics by Brycon devillei for each season in the RPSP, between July 2006 and April 2009.

L. garmani stopped its foraging activities to move to other feeding sites.

This nuclear-follower interaction had a mean duration of $13.6 \mathrm{~min} \pm 9.3(\mathrm{~N}=53)$ and such events frequently occurred more than once during the 120 min observation session. While we observed a maximum ratio of one individual of $L$. garmani to about three $B$. devillei, feeding association events comprised almost always (83.4\%) only one individual of each species. The Pearson's correlation between this social interspecific behavior and the foraging frequency of $B$. devillei was significant and negative $(\mathrm{r}=-0.669, \mathrm{~N}=12, \mathrm{p}<0.05)$.

\section{Discussion}

Overall, the feeding behavior of $B$. devillei showed variation in relation to its foraging tactics. However, the species proved to be a specialist surface forager, which at certain times of the year adopted alternative tactics to search for food. This change probably occurred when food resources on the surface of the water became scarce. Foraging frequency was shown to be negatively correlated with agonistic behavior between conspecifics and with feeding associations with $L$. garmani.

\section{Feeding and social behavior of Brycon devillei}

Unfortunately, it was not possible to identify food items consumed by $B$. devillei. Therefore, it is suggested that future studies should use high-speed and high resolution video cameras (High Speed Camera) for accurate documentation of food items at the time of capture. In addition, studies measuring food availability in the environment are necessary. It was decided not to collect specimens for analysis of stomach contents at the sampled points, in order to avoid the loss of individuals for observations in a biological conservation area.

The three foraging tactics of $B$. devillei, observed in this study demonstrate the broad behavioral spectrum of food acquisition behavior in this species. This feature corroborates the omnivorous habits of the genus, as observed in several 


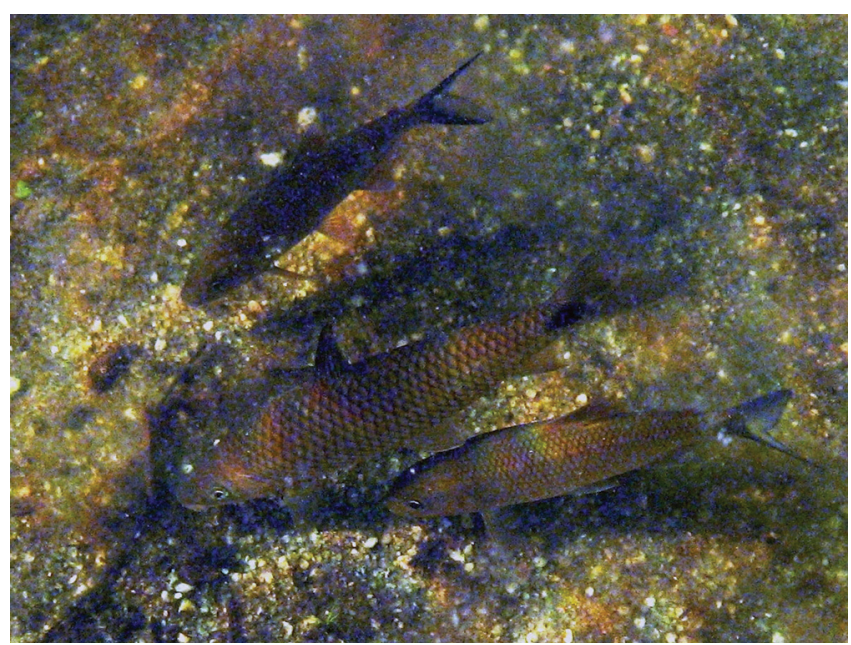

Fig. 3. Two individuals of Brycon devillei aligned sideways to the timburé, Leporinus garmani, on a sand bank in the rio Preto channel. Photo by P. G. Azevedo.

other studies (Breeder, 1927; Menezes, 1969; Knöpell, 1970; Goulding, 1980; Borges, 1986; Horn, 1997; Sabino \& Sazima, 1999; Lima \& Castro, 2000; Leite \& Araujo-Lima, 2002; Drewe et al., 2004; Leite, 2004; Albrecht et al., 2009). These studies show a considerable range of food items consumed by the Brycon species such as: plant debris, terrestrial and aquatic insects, small fish, and terrestrial vertebrates. However, despite this variety of feeding behavior, statistical analyzes on the frequency of occurrence between foraging tactics indicated a preference for surface-picking; this has also been found in other species of the family Characidae (Sazima, 1986; Casatti, 2002). This tendency may be related to contribution of allochthonous drift material, whose importance for feeding of Brycon has been documented in other studies (Goulding, 1980; Horn, 1997; Sabino \& Sazima, 1999; Lima \& Castro, 2000). Santos et al. (pers. comm.) analyzed the stomach contents of 20 specimens of $B$. devillei and detected as major items in their diet, terrestrial insects and plant debris. This reinforces the finding of a preference for foraging on the surface of the water body, and consequently highlighting the need for conservation of riparian areas.

Moreover, when analyzing the mean frequency of each foraging tactic, it was found that there was no statistically significant difference between surface-picking and digging. This fact was probably related to the degree of difficulty in detecting food items in the environment. Food items available at the water's surface were apparently easier to detect because of the visual contrast between the surface of water and land environment, or even because of the vibration produced by the fall of the food items onto the water. On the other hand, food items on the bottom were probably more difficult to detect due to structural complexity of this substrate, consisting of sand, litter, logs, submerged branches, rocks, and underwater vegetation. The same inference could be made for active-hunting (modified from Keenleyside, 1979), essentially characterized by the hunt for characins (Astyanax spp.), which was the least used tactic by $B$. devillei. This hunting behavior in schools resembled a coordinated method to separate the prey from a group, as observed in groups of dolphins (Stenella frontalis and Lagenorhynchus obscurus) when hunting fish (McKinnon, 1994; Fertl \& Würsig, 1995; McFadden \& Joy, 2003); this behavior has not yet been described for any species of the genus Brycon, or even for the family Characidae. Although active-hunting was recorded as the least common foraging tactic, in April it was more frequent than other tactics. Feeding events involving hunts are generally costly in terms of energy (Savino \& Stain, 1989); thus, for B. devillei, the consumption of Astyanax spp. could be interpreted as an opportunistic food source during periods of low food availability (especially those of allochthonous origin).

Data analyzed for the expression of seasonal foraging behavior of $B$. devillei suggested that, in the dry and rainy seasons, different tactics were used with different intensities (Fig. 2). This behavioral plasticity can be seen as an expression of the ability of fish to utilize other food when preferred items were in short supply (Knöpel, 1970). A significantly higher feeding frequency was observed in the rainy season when compared to the dry season, mainly due to the expression of surface-picking (Fig. 2). In general, the rainy season presents greater food availability in comparison with the dry season in some Brazilian rivers (Zaret \& Rand, 1971; Payne, 1986; Prejs \& Prejs, 1987). Furthermore, as emphasized by Junk (1980), hydrological changes may affect not only the quantity, but also the quality of food in aquatic systems. The importance of terrestrial invertebrates as food resources for fish is evident in tropical streams (LoweMcConell, 1975), which is also observed for B. devillei (Santos et al., pers. comm.). According to Angermeier \& Karr (1983), terrestrial insects are more abundant in water sources during the rainy season due to increased primary productivity at this time and due to mechanical action of washing by rain. This explains the observation, in the present study, of a higher frequency and higher mean expression of surface-picking during the rainy season.

From a social behavior point of view, $B$. devillei live in groups, one of the most striking aspects of animal behavior (Bertram, 1978; Pulliam \& Caraco, 1984), especially for fish (Godin, 1986; Magurran, 1990; Pitcher \& Parrish, 1993). Individuals in schools have reduced risk of predation due to increased surveillance by the group (Foster \& Treherne, 1981; Magurran et al., 1985; Morgan \& Godin, 1985; Godin et al., 1988 ) and experience foraging benefits, since there are many eyes to look for food (Pitcher et al., 1982; Pitcher \& Magurran, 1983). However, the strategy of living in groups increases the competition for food in the school (Bertram, 1978). It is believed that this is a major cost of sociality (Ranta \& Kaitala, 1991) and can intensify hierarchical behavior between individuals (e.g. agonistic behavior; David et al., 2007). It is clear that the conspecific aggression of $B$. deville $i$ was more intense during the months of the dry season, and had a negative correlation with feeding frequency. Dominance hierarchy, particularly in 
fish, may be initially determined by the competition for available food resources (David et al., 2007). In addition, this plays a key role in resolving spatial and temporal patterns of activity and habitat use of many stream fish. Dominant individuals in the school usually occupy the most profitable positions of group in terms of food encounter rate (Bachman, 1984; Hughes 1992a, 1992b; Nakano, 1995).

Although conspecific aggression can indicate a dominance hierarchy, it was not possible to recognize any kind of dominance within the schools of $B$. devillei, due to the absence of variation in physical characteristics of the fish it was not possible to identify individuals. Thus, it is recommended that future studies should use external marks on fish, which would permit quick and precise identification of individuals.

\section{Feeding association of nuclear-following behavior}

Species of Leporinus are considered to be mainly bottomassociated feeders, due to the presence of sediment and benthic organisms such as insect larvae and filamentous algae in their stomach contents (Albrecht et al., 2003a, 2003b). This assumption is also supported by the species' sub-terminal mouth (Albrecht et al., 2001), although mouth arrangement is not always a strong indicator of feeding habit for anostomids (Santos \& Rosa, 1998). Sazima, (1986) also reported a case of nibbling tactic for Leporinus lacustris, which is a type of bottom feeding. However, observations in the present study indicated that $L$. garmani was an obligate digger (sensu Sazima, 1986). In view of its feeding habits, such anostomid visibly played the nuclear role in the feeding associations herein described. While this role is not only performed by bottom disturbing organisms, substrate disturbance is considered a strong predictor of the nuclear task in a nuclear-follower association (Strand, 1988; Sazima et al., 2006; Krajewski, 2009).

Social interactions between B. devillei and L. garmani were higher in the dry season and correlated negatively with feeding frequency. Some studies have shown that a major function of interspecific association is to maximize the capture of food items during foraging (Dubin, 1982; Lukoschek \& McCormick, 2000; Teresa \& Carvalho, 2008). The ability of fish to utilize the resources available, as in association between species, may be essential to guarantee their survival, especially during periods of food scarcity (Baker \& Foster, 1994). But, why L. garmani do not become aggressive with this opportunistic behavior of $B$. devillei, since both species fed on the same food? This exploitation may be possible due to the benefits of group feeding, such as improving predator avoidance and food detection. The hypothesis of predator avoidance seems more consistent with our observations, since two predation events were recorded on $B$. devillei by Hoplias spp. (PGA pers. obs.), which can also represent a risk for L. garmani. In terms of the fish community, species of Hoplias seem to be the only potential predator at our study sites. Nevertheless, according to local people, other potential predators of fishes such as otters (Lontra longicaudis) and alligators (Paleosuchus palpebrosus) were present.

In conclusion, the behavioral plasticity of $B$. devillei in food acquisition, as well as variations in social behavior of the species, probably arises from the seasonal distribution of the different food resources. Despite being mainly a surfacepicker, $B$. devillei depends on alternative food sources to survive in periods when the surface of the water becomes less productive. This fact also influences their interspecific and intraspecific relationships. Further studies are needed to address the quantification and identification of seasonal food availability. Concerning the interspecific foraging associations, we believe that its basis appears was to increase the range of usable resources, such as food and space, for individuals and/or groups of fishes participating in these associations. In addition, we predict that a series of factors acting together promote the expression of this behavior, for example, the same activity period, the benefits of group foraging and the use of the same feeding sites.

\section{Acknowledgements}

We wish to thank professors Flávio Lima, Evanguedes Kalapothakis and Hugo Godinho for providing helpful comments on this article. RJY receives logistic and financial support from IEF, FAPEMIG, PUC Minas and CNPq. This paper was written while PGA was in receipt of a CAPES postgraduate scholarship. We are extremely grateful to all the workers from the RPSP who provided logistical support for our study.

\section{Literature Cited}

Ab'Saber, A. N. 1977. Os domínios morfoclimáticos na América do Sul. Primeira aproximação. Geomorfológica, 52: 1-21.

Agostinho, A. A., E. Zaniboni-Filho \& F. C. T. Lima. 2008. Brycon orbygnianus (Valenciennes, 1850). Pp. 54-56. In: Machado A., G. Drummond \& C. Martins (Eds.). Livro Vermelho da Fauna Brasileira Ameaçada de Extinção. Brasília, Fundação Biodiversitas, 907p.

Albrecht, M. P. \& E. P. Caramaschi. 2003a. Feeding Ecology of Leporinus friderici (Teleostei; Anostomidae) in the upper Tocantins river, central Brazil, before and after installation of a hydroelectric plant. Studies on Neotropical Fauna and Environment, 38: 33-40.

Albrecht, M. P. \& E. P. Caramaschi. 2003b. Feeding Ecology of Leporinus taeniofasciatus (Characiformes: Anostomidae) before and after installation of a hydroelectric plant in the upper rio Tocantins, Brazil. Neotropical Ichthyology, 1: 53-60.

Albrecht, M. P., E. P. Caramaschi \& M. H. Horn. 2009. Population responses of two omnivorous fish species to impoundment of a Brazilian tropical river. Hydrobiologia, 627: 181-193.

Albrecht, M. P., M. F. N. Ferreira \& E. P. Caramaschi. 2001. Anatomical features and histology of the digestive tract of two related neotropical omnivorous fishes (Characiformes; Anostomidae). Journal of Fish Biology, 58: 1419-1430.

Angermeier, P. L. \& J. R. Karr. 1983. Fish communities along environmental gradients in a system of tropical streams. Environmental Biology of Fish, 9: 117-135.

Azevedo, P. G., F. O. Mesquita \& R. J. Young. 2010. Fishing for gaps in science: a bibliographic analysis of Brazilian freshwater ichthyology from 1986 to 2005. Journal of Fish Biology, 76: 2177-2193. 
Bachman, R. A. 1984. Foraging behavior of free-ranging wild and hatchery brown trout in a stream. Transactions of the American Fisheries Society, 113: 1-32.

Baker, J. A. \& S. A. Foster. 1994. Observations on a foraging association between two freshwater stream fishes. Ecology of Freshwater Fish, 3: 137-139.

Banack, S. A., M. H. Horn \& A. Gawlicka. 2002. Disperser- vs. establishment-limited distribution of a riparian fig tree (Ficus insipida) in a Costa Rican tropical rain forest. Biotropica, 34: 232-243.

Bertram, B. C. R. 1978. Living in groups: predators and prey. Pp. 64-96. In: Krebs, J. R. \& N. B. Davies (Eds.). Behavioural Ecology: An Evolutionary Approach. Oxford, Blackwell, 468p.

Borges, G. A. 1986. Ecologia de três espécies do gênero Brycon Muller \& Troschel, 1844 (Pisces, Characidae), no rio NegroAmazonas, com ênfase na caracterização taxonômica e alimentação. Unpublished Ph.D. Dissertation, INPA/FUA, Manaus, 150p.

Breeder, C. M. 1927. The fishes of the rio Chucunaque drainage eastern Panamá. Bulletin of the American Museum of Natural History, 57: 91-176.

Burcham, J. 1988. Fish communities and environmental characteristics of two lowland streams in Costa Rica. Revista de Biologia Tropical, 36: 273-285.

Carvalho, L. N., R. Arruda \& J. Zuanon. 2003. Record of cleaning behavior by Platydoras costatus (Siluriformes: Doradidae) in the Amazon Basin, Brazil. Neotropical Ichthyology, 1: 137-139.

Casatti, L. 2002. Alimentação dos peixes em um riacho do Parque Estadual Morro do Diabo, bacia do alto rio Paraná, sudeste do Brasil. Biota Neotropica, 2: 1-14.

Cody, M. L. 1971. Finch flocks in the Mohave Desert. Theoretical Population Biology. 2: 142-158.

Crook, J. H. 1965. The adaptive significance of avian social organizations. Symposia of the Zoological Society of London, 14: 181-218.

David, B. O., G. P. Closs, S. K. Crow \& A. H. Eric. 2007. Is diel activity determined by social rank in a drift-feeding stream fish dominance hierarchy? Animal Behaviour, 74: 259-263.

Drewe, K. E., M. H. Horn, K. A. Dickson \& A. Gawlicka. 2004. Insectivore to frugivore: ontogenetic changes in gut morphology and digestive enzyme activity in the characid fish Brycon guatemalensis from Costa Rican rain forest streams. Journal of Fish Biology, 64: 890-902.

Dubin, R. E. 1982. Behavioral Interactions between Caribbean Reef Fish and Eels (Muraenidae and Ophichthidae). American Society of Ichthyologists and Herpetologists, 1982: 229-232.

Fertl, D. \& B. Würsig. 1995. Coordinated feeding by Atlantic spotted dolphins (Stenella frontalis) in the Gulf of Mexico. Aquatic Mammals, 21: 3-5.

Foster, W. \& J. E. Treherne. 1981. Evidence for the dilution effect in the selfish herd from fish predation on a marine insect. Nature, 293: 466-467.

Fréon, P., F. Gerlotto \& M. Soria. 1992. Changes in school structure according to external stimuli: description and influence on acoustic assessment. Fisheries Research, 15: 45-66.

Fricke, H. W. 1975. The role of behaviour in marine symbiotic animals. Pp. 581-594. In: Jennings, D. H. \& D. L. Lee (Eds.). Symbiosis, Symposia of the Society for Experimental Biology, 29. Cambridge University Press, Cambridge, 633p.

Garrone-Neto, D. \& I. Sazima. 2009. The more stirring the better: cichlid fishes associate with foraging potamotrygonid rays. Neotropical Ichthyology, 7: 499-501.
Godin, J-G. J. 1986. Anti-predator function of shoaling in teleost fishes: a selective review. Naturalist Canadien, 113: 241-250.

Godin, J-G. J., L. J. Classon \& M. V. Abrahams. 1988. Group vigilance and shoal size in a small characin fish. Behaviour, 104: 29-40.

Godinho, H. P., A. L. Godinho \& V. Vono. 1999. Peixes da bacia do rio Jequitinhonha. Pp. 414-423. In: Lowe-McConnell R.H. (Ed.). Estudos ecológicos de comunidades de peixes tropicais. São Paulo, EDUSP, 534p.

Godoy, M. P. 1975. Peixes do Brasil: subordem Characoidei, bacia do rio Mogi Guassu. Piracicaba, SP, Ed. Franciscana, 847p.

Goulding, M. 1980. The Fishes and the forest: Explorations in Amazonian Natural History. University of California Press. Berkeley, California, 280p.

Horn, M. H. 1997. Evidence for dispersal of fig seeds by the fruiteating characid fish Brycon guatemalensis Regan in a Costa Rican tropical rain forest. Oecologia, 109: 259-264.

Hughes, N. F. 1992a. Ranking of positions by drift-feeding salmonids in dominance hierarchies: model and test for Arctic grayling (Thymallus arcticus) in sub-Arctic mountain streams, interior Alaska. Canadian Journal of Fisheries and Aquatic Sciences, 49: 1994-1998.

Hughes, N. F. 1992b. Selection of positions by drift-feeding salmonids in dominance hierarchies: model and test for Arctic grayling (Thymallus arcticus) in sub-Arctic mountain streams, interior Alaska. Canadian Journal of Fisheries and Aquatic Sciences, 49: 1999-2008.

Junk, W. J. 1980. Áreas inundáveis: um desafio para a limnologia. Acta Amazonica, 10: 775-796.

Keenleyside, M. H. A. 1979. Diversity and Adaptation in Fish Behavior. Berlin, Springer-Verlag, 208p.

Krajewski, J. P. 2009. How do follower reef fishes find nuclear fishes? Environmental Biology of Fishes. 86: 379-387.

Krebs, J. R. 1973. Social learning and the significance of mixedspecies flocks of chickadees (Parus spp.). Canadian Journal of Zoology, 51: 1275-1288.

Lehner, P. N. 1998. Handbook of Ethological Methods. 2 ed. Cambridge University Press, 672p.

Leitão, R. P., E. P. Caramaschi \& J. Zuanon. 2007. Following food clouds: feeding association between a minute loricariid and a characidiin species in an Atlantic Forest stream, Southeastern Brazil. Neotropical Ichthyology, 5: 307-310.

Leite, R. G. 2004. Alimentação de juvenis de matrinxã, Brycon amazonicum (Pisces, Characidae), em áreas inundadas da Ilha de Marchantaria, Amazonas, Brasil. Acta Amazonica, 34: 661-664.

Leite, R. G. \& C. A. R. M. Araujo-Lima. 2002. Feeding of the Brycon amazonicum, Triportheus elongatus, and Semaprochilodus insignis (Osteichthyes, Caraciformes), larvae in Solimões/ Amazonas river and floodplain areas. Acta Amazônica, 3: 56-67.

Lima, F. C. T. 2003. Subfamily Bryconinae. Pp. 174-181. In: Reis, R. E., S. O. Kullander \& C. J. Ferraris, (Eds.). Check List of the Freshwater Fishes of South and Central America. Porto Alegre, EDIPUCRS, 742p.

Lima, F. C. T. 2004. Brycon gouldingi, a new species from the rio Tocantins drainage, Brazil (Ostariophysi: Characiformes: Characidae), with a key to the species in the basin. Ichthyological Exploration of Freshwaters, 15: 279-287.

Lima, F. C. T., M. P. Albrecht, C. S. Pavanelli \& V. Vono. 2008. Threatened fishes of the world: Brycon nattereri Günther, 1864 (Characidae). Environmental Biology of Fishes, 83: 207-208. 
Lima, F. C. T. \& R. M. C. Castro. 2000. Brycon vermelha, a new species of characid fish from the Rio Mucuri, a coastal river of eastern Brazil (Ostariophysi: Characiformes). Ichthyological Exploration of Freshwaters, 11: 155-162.

Lowe-McConnell, R. H. 1964. The fishes of the Rupununi savanna district of British Guiana, Pt. 1. Groupings of fish species and effects of seasonal cycles on the fish. Zoological Journal of the Linnean Society, 45: 103-144.

Lukoschek, V. \& M. I. McCormick. 2000. A review of multi-species foraging associations in fishes and their ecological significance. Proceedings 9th International Coral Reef Symposium, Bali, Indonésia, 23-27.

Magurran, A. E. 1990. The adaptive significance of schooling as an anti-predator defence in fish. Annales Zoologici Fennici, 27: 51-66.

Magurran, A. E., W. Oulton \& T. J. Pitcher. 1985. Vigilant behaviour and shoal size in minnows. Zeitschrift für Tierpsychologie, 67: 167-178.

McFadden \& Joy, C. 2003. Behavioral flexibility of feeding dusky dolphins (Lagenorhynchus obscurus) in Admiralty Bay, New Zealand. Unpublished Ph.D. Dissertation, Texas A\&M University, Texas, 92p.

Menezes, N. A. 1969. The food of Brycon and three closely related genera of the tribe Acestrorhynchini. Papéis Avulsos de Zoologia, 22: 217-223.

Morgan, M. J. \& J-G. J. Godin. 1985. Antipredator benefits of schooling behaviour in a cyprinodontid fish, the banded killifish (Fundulus diaphanus). Zeitschrift für Tierpsychologie, 70: 236-246.

Nakano, S. 1995. Competitive interactions for foraging microhabitats in a size-structured interspecific dominance hierarchy of two sympatric stream salmonids in a natural habitat. Canadian Journal of Zoology, 73: 1845-1854.

Oliveira, F. F. R. \& P. C. Eterovick. 2010. Patterns of spatial distribution and microhabitat use by syntopic anuran species along permanent lotic ecosystems in the Cerrado of southeastern Brazil. Herpetologica, 66: 148-160.

Payne, A. I. 1986. The ecology of tropical lakes and rivers. John Wiley \& Sons, 301p.

Pitcher, T. J. \& A. E. Magurran. 1983. Shoal size, patch profitability and information exchange in foraging goldfish. Animal Behaviour, 31: 546-555.

Pitcher, T. J., A. E. Magurran \& I. J. Winfield. 1982. Fish in larger shoals find food faster. Behavioral Ecology and Sociobiology, 10: 149-151.

Pitcher, T. J. \& J. K. Parrish. 1993. Functions of shoaling behaviour in teleosts. Pp. 363-439. In: Pitcher, T. J. (Ed.). Behaviour of Teleost Fishes. London, Chapman \& Hall, 740p.

Pulliam, H. R. \& T. Caraco. 1984. Living in groups: is there an optimal group size? Pp. 122-147. In: Krebs, J. R. \& N. B. Davies. (Eds.). Behavioural Ecology: An Evolutionary Approach. $2^{\text {nd }}$ ed., Oxford, Blackwell Science, 468p.
Ranta, E. \& V. Kaitala. 1991. School size affects individual feeding success in three-spined sticklebacks (Gasterosteus aculeatus). Journal of Fish Biology, 39: 733-737.

Rizzini, C.T. 1979. Tratado de fitogeografia do Brasil. São Paulo, EDUSP/HUCITEC, 374p.

Rosa, R. S. \& F. C. T. Lima. 2008. Peixes. Pp. 9-19. In: Machado, A. B., C. S. Martins \& G. M. Drummond. (Eds.). Livro Vermelho da Fauna Brasileira Ameaçada de Extinção. Brasília, Biodiversitas, 907p.

Sabino, J. \& I. Sazima. 1999. Association between fruit-eating fish and foraging monkeys in western Brazil. Ichthyological Exploration of Freshwaters, 10: 309-312.

Santos, G. M. \& P. S. Rosa. 1998. Alimentação de Anostomus ternetzi e Synaptolaemus cingulatus, duas espécies de peixes amazônicos com boca superior. Revista Brasileira de Biologia, 58: 255-262.

Savino, J. F. \& R. A. Stain. 1989. Behavior of fish predators and their prey: habitat choice between open water and dense vegetation. Environmental Biology of Fishes, 24: 287-293.

Sazima, I. 1986. Similarities in feeding behaviour between some marine and freshwater fishes in two tropical communities. Journal of Fish Biology, 29: 53-65.

Sazima, I. \& A. Grossman. 2006. Turtle riders: remoras on marine turtles in Southwest Atlantic. Neotropical Ichthyology, 4: 123-126.

Sazima, C., A. Grossman, C. Bellini \& I. Sazima. 2004. The moving gardens: reef fishes grazing, cleaning, and following green turtles in SW Atlantic. Cybium, 28: 47-53.

Sazima, I. \& F. A. Machado. 1990. Underwater observations of piranhas in western Brazil. Environmental Biology of Fishes, 28: $17-31$.

Sazima, I., C. Sazima \& J. M. Silva-Jr. 2006. Fishes associated with spinner dolphins at Fernando de Noronha Archipelago, tropical Western Atlantic: an update and overview. Neotropical Ichthyology, 4: 451-455.

Siegel, S. 1975. Estatística não Paramétrica: Para as Ciências do Comportamento. São Paulo, Ed. McGraw-Hill do Brasil, 350p.

Strand, S. 1988. Following behavior: interspecific foraging associations among Gulf of California reef fishes. Copeia 1988:351-357.

Teresa, F. B. \& F. R. Carvalho. 2008. Feeding association between benthic and nektonic Neotropical stream fishes. Neotropical Ichthyology, 6: 109-111

Zar, J. H. 1999. Biostatistical analysis. 4a. ed., New Jersey, Prentice Hall, 663p.

Zaret, T. M. \& A. S. Rand. 1971. Competition in tropical stream fishes: support for the competitive exclusion principle. Ecology, 52: $336-342$.

Submitted November 24, 2010

Accepted August 25, 2011

Published December 26, 2011 